\title{
Hubungan Pola Makan dan Aktivitas Fisik Dengan Kejadian Obesitas Pada Anak
}

\author{
dr. Elvie Febriani Dungga, M.Kes \\ Program Studi Ilmu Keperawatan FOK UNG \\ Email: elviefebrianidungga@yahoo.com
}

\begin{abstract}
Abstrak
Obesitas merupakan masalah kesehatan yang penting, selain karena merupakan faktor risiko timbulnya penyakit kronis degenerative dikemudian hari, obesitas juga sudah banyak menimbulkan masalah pada usia anak dan remaja. Tujuan dari penelitian ini adalah untuk mengetahui hubungan pola makan dan aktivitas fisik dengan kejadian obesitas di SD Laboratorium Universitas Negeri Gorontalo (UNG). Jenis penelitian ini merupakan penelitian kuantitatif dengan metode observasional analitic melalui pendekatan Cross Sectional. Populasi sebanyak 150 orang. Sampel penelitian sebanyak 121 orang yang diambil dengan teknik purposive sampling. Hasil penelitian pada analisa bivariat menunjukan bahwa ada hubungan antara pola makan dan aktivitas fisik ( $\mathrm{P}-$ Value $=0,000)$, dengan kejadian obesitas pada anak di SD Labratorium Universitas Negeri Gorontalo (UNG). Diharapkan pada pihak sekolah agar memperhatikan status gizi siswa/siswi, karena status gizi yang buruk akan berdampak negatif bagi kondisi kesehatan anak.
\end{abstract}

Kata kunci : aktivitas fisik, obesitas

\begin{abstract}
Obesity is an important health problem, aside from being a risk factor for chronic degenerative diseases in the future, obesity has also caused many problems in children and adolescents. The purpose of this study was to determine the relationship between eating patterns and physical activity with the incidence of obesity in SD Negeri Gorontalo (UNG) Laboratory. This type of research is a quantitative study with observational analytic methods through a cross sectional approach. The population is 150 people. The research sample of 121 people taken by purposive sampling technique. The results of the bivariate analysis showed that there was a relationship between eating patterns and physical activity (P-Value $=0,000)$, with the incidence of obesity in children in the SD Labratorium Gorontalo State University (UNG). It is expected that schools will pay attention to the nutritional status of students, because poor nutritional status will have a negative impact on children's health conditions.
\end{abstract}

Keywords: obesity, physical activity

\section{PENDAHULUAN}

Anak sekolah merupakan golongan yang mempunyai karakteristik mulai mencoba mengembangkan kemandirian dan menentukan batasan-batasan normal (Yatim,2008). Menurut WHO (World Health Organization) anak sekolah berusia antara 7-15 tahun. Pada tahap ini individu mulai lebih mudah dikenali seperti pertumbuhan dan perkembangannya, pola aktivitas, kebutuhan zat gizi, perkembangan kepribadian, serta asupan makanan. Pertumbuhan adalah perubahan dalam besar, jumlah, ukuran, maupun individu yang bisa diukur sedangkan perkembangan adalah bertambahnya kemampuan dalam struktur dan fungsi tubuh yang lebih kompleks dalam pola yang teratur dan dapat diramalkan, sebagai hasil dari proses pematangan (Nirwana, 2012). 
Pada usia sekolah dasar, anak akan mengalami banyak perubahan dalam tubuh mereka, salah satunya adalah masalah obesitas. Obesitas merupakan kelebihan lemak tubuh (WHO, 2015). Obesitas juga didefinisikan sebagai suatu kelainan yang ditandai dengan penimbunan jaringan lemak tubuh secara berlebihan (Nirwana, 2012).

Obesitas pada anak merupakan masalah kesehatan karena prevalensi obesitas anak di dunia semakin meningkat. Dampak dari gizi lebih tidak sekedar mengganggu estetika penampilan, tetapi menjadi predisposisi atau pemicu faktor resiko berbagai penyakit tidak menular baik degeneratif maupun kardiovaskular. Selain itu, gangguan pernapasan atau asma juga salah satu penyakit yang menyerang anakanak yang mengalami obesitas. Anak-anak yang mengalami kelebihan berat badan juga sering mengalami gangguan bergerak dan terganggu pertumbuhannya karena timbunan lemak yang berlebihan pada organ-organ yang seharusnya berkembang (Nirwana, 2012).

Prevalensi obesitas berdasarkan WHO pada anak usia 5-17 tahun yakni $10 \%$ (Depkes RI, 2007). Berdasarkan penelitian yang dilakukan di 188 negara di dunia menyebutkan bahwa overweight dan obesitas pada anak dan remaja di dunia dari tahun 1980-2013 mengalami peningkatan yaitu di negara maju 23,8\% pada laki-laki dan $22,6 \%$ pada perempuan, sedangkan di negara berkembang dari $8,1 \%$ menjadi $12,9 \%$ pada laki-laki dan dari $8,4 \%$ menjadi $13,4 \%$ pada anak perempuan $(\mathrm{Ng}, 2014)$.

Menurut data Riset Kesehatan Dasar (Riskesdas) tahun 2007, prevalensi obesitas di Indonesia pada anak usia 6-14 tahun sebesar 7,95\%. Data Riskesdas tahun 2010 prevalensi anak usia sekolah 6-12 tahun yang mengalami obesitas pada tahun 2010 sebesar 9,2 \%. Hingga tahun 2013 data Riskesdas, prevalensi overweight dan obesitas pada anak usia 5-12 tahun mencapai $18,8 \%$.

Berdasarkan status gizi anak yang mengalami obesitas usia 6-14 tahun menurut IMT pada laki-laki dan perempuan di Provinsi Gorontalo sebesar 4,8\%. Prevalensi obesitas di Kabupaten Boalemo 6,6\%, di Kabupaten Gorontalo 2,8\%, di Kabupaten Pohuwato 4,05\%, di Kabupaten Bone Bolango $4,45 \%$, dan yang paling tertinggi prevalensi obesitas terdapat di Kota Gorontalo yakni 9,25\% (Riskesdas, 2007).

Data tahun 2016 oleh Dinas Kesehatan Provinsi Gorontalo yang melakukan penjaringan kesehatan anak sekolah di 
seluruh SD se-Provinsi Gorontalo, anak yang terjaring kesehatannya sebanyak 12.437 orang dan yang mengalami obesitas sebanyak 71 anak. Begitupun pada tahun 2017, anak yang terjaring kesehatannya sebanyak 20.308 orang dan yang mengalami obesitas sebanyak 159 anak. Dari hasil tersebut, setiap tahun prevalensi obesitas semakin meningkat dan kurangnya perhatian dari pemerintah sehingga akan berdampak pada kesehatan anak di masa yang akan datang. (Dinas Kesehatan Provinsi Gorontalo, 2018).

Faktor-faktor yang menyebabkan anak mengalami obesitas dikelompokkan menjadi 4 kelompok yakni pertama faktor genetik. Faktor genetik tersebut yakni kondisi orang tua yang memiliki berat badan yang lebih, maka hal tersebut bisa di pastikan akan menurun pada anaknya. Kedua faktor sosial ekonomi yakni anak yang berasal dari keluarga dengan pendapatan keluarga yang tinggi akan meningkatkan peluang untuk membeli pangan dengan kualitas dan kuantitas yang lebih baik, sebaliknya penurunan pendapatan dalam keluarga akan menyebabkan menurunnya daya beli pangan baik kualitas maupun kuantitas. Ketiga adalah penurunan aktifitas fisik, dimana anak kurang beraktifitas diluar rumah dan lebih memilih untuk menonton TV maupun bermain game online. Keempat adalah pola konsumsi makanan yang terjadi karena ketidakseimbangan antara asupan energi yang dikonsumsi dengan energi yang digunakan (Suhendro, 2007).

Hal ini juga ditemui pada penelitian yang dilakukan oleh Rachmatia \& Fitri (2012) menunjukan bahwa ada hubungan yang signifikan antara faktor lingkungan pola makan dan aktifitas fisik dengan tingkat obesitas, dan faktor psikologis dengan tingkat obesitas anak, sedangkan faktor genetik tidak terdapat hubungan yang signifikan dengan tingkat obesitas anak.

Berdasarkan hasil survei yang dilakukan peneliti pada

tanggal 8 Februari 2018 di SD LAB Kota Selatan Gorontalo. Melalui wawancara peneliti bersama Kepala Sekolah ternyata di sekolah tersebut ada beberapa siswa yang memiliki berat badan lebih yang tidak sesuai dengan usia anak tersebut. Hasil pemeriksaan TB dan BB yang dilakukan oleh peneliti didapatkan IMT ke-5 responden (anak sekolah dasar) berada dalam kategori obesitas dimana Z-Score $>2$ SD. Hasil wawancara yang dilakukan 
Vol. 2, No. 1, January, 2020

Jambura Nurisng Journal

pISSN: 2654-2927 eISSN: 2656-4653

terhadap 5 orang anak didapatkan hasil

bahwa semua anak tersebut sudah tahu jika

mereka memiliki berat badan lebih

namun mereka tidak tahu jika mereka sudah

berada dalam kategori obesitas. Empat

orang anak mengatakan frekuensi makan

setiap hari sebanayak 2 kali dan 1 orang

mengatakan frekuensi makan 3-4 kali sehari.

3 orang anak mengatakan jika mereka lebih

banyak menghabiskan waktu di dalam rumah dengan bermain game dan nonton TV, sedangkan 2 anak lainnya sering bermain dengan teman-teman disekitar rumah. 4 dari 5 anak tersebut mengatakan bahwa orang tua mereka gemuk. Berdasarkan uraian diatas maka peneliti tertarik untuk meneliti "Hubungan Pola Makan dan Aktivitas Fisik Dengan Kejadian Obesitas Pada Anak di SD Laboratorium UNG"

\section{METODOLOGI PENELITIAN}

\begin{tabular}{|c|c|c|c|c|c|c|c|}
\hline \multirow{3}{*}{$\begin{array}{c}\text { Aktivitas } \\
\text { Fisik }\end{array}$} & \multicolumn{4}{|c|}{ Obesitas } & \multirow{2}{*}{\multicolumn{2}{|c|}{ Total }} & \multirow{3}{*}{$\begin{array}{c}\text { P- } \\
\text { Val } \\
\text { ue }\end{array}$} \\
\hline & \multicolumn{2}{|c|}{ Ya } & \multicolumn{2}{|c|}{ Tidak } & & & \\
\hline & $\mathrm{N}$ & $\%$ & $\mathrm{~N}$ & $\%$ & $\mathrm{~N}$ & $\%$ & \\
\hline Baik & 0 & 0 & 55 & 45,5 & 55 & 45,5 & $\begin{array}{l}0,0 \\
00\end{array}$ \\
\hline $\begin{array}{l}\text { Tidak } \\
\text { Baik }\end{array}$ & 63 & 52,1 & 3 & 2,4 & 66 & 54,5 & \\
\hline Jumlah & 63 & 52,1 & 58 & 47,9 & 121 & 100 & \\
\hline
\end{tabular}

Jenis penelitian ini merupakan

penelitian kuantitatif dengan metode observasional analitic melalui pendekatan
Cross Sectional. Populasi sebanyak 150 orang. Sampel penelitian sebanyak 121

\begin{tabular}{|c|c|c|c|c|c|c|c|}
\hline \multirow{3}{*}{$\begin{array}{c}\text { Pola } \\
\text { Makan }\end{array}$} & \multicolumn{4}{|c|}{ Obesitas } & & & \multirow{3}{*}{$\begin{array}{c}\text { P- } \\
\text { Value }\end{array}$} \\
\hline & \multicolumn{2}{|c|}{ Ya } & \multicolumn{2}{|c|}{ Tidak } & \multicolumn{2}{|c|}{ Total } & \\
\hline & $\mathrm{N}$ & $\%$ & $\mathrm{~N}$ & $\%$ & $\mathrm{~N}$ & $\%$ & \\
\hline Baik & 23 & 19 & 33 & 27,2 & 56 & 46,3 & 0,039 \\
\hline $\begin{array}{l}\text { Tidak } \\
\text { Baik }\end{array}$ & 40 & 33,1 & 25 & 20,7 & 65 & 53,7 & \\
\hline Jumlah & 63 & 52,1 & 58 & 47,9 & 121 & 100 & \\
\hline
\end{tabular}

orang yang diambil dengan teknik purposive sampling.

\section{HASIL PENELITIAN}

1. Hubungan pola makan dengan kejadian obesitas pada anak di SD Laboratorium Universitas Negeri Gorontalo

Sumber Data Primer, 2018

Dari hasil penelitian yang dilakukan pada 121 responden, didapatkan bahwa responden dengan pola makan tidak baik sebanyak 65 responden $(53,7 \%)$ dan pola konsumsi makan baik sebanyak 56 responden $(46,3 \%)$. Dengan hasil analisis data menunjukan P-Value $=0,039<\alpha=$ 0,05, angka ini memberikan arti bahwa terdapat hubungan antara pola makan dengan kejadian obesitas pada anak.

2. Hubungan aktivitas fisik dengan kejadian obesitas pada anak di SD Laboratorium Universitas Negeri Gorontalo

Sumber :Data Primer, 2018 
Dari hasil penelitian yang dilakukan

pada 121 responden, didapatkan bahwa responden yang melakukan aktivitas fisik dengan tidak baik sebanyak 66 orang $(54,5 \%)$ dan responden yang melakukan aktivitas fisik dengan baik sebanyak 55 orang $(45,5 \%)$. Dengan hasil analisis data menunjukan P-Value $=0,000<\alpha=0,05$, angka ini memberikan arti bahwa terdapat hubungan antara aktivitas fisik dengan kejadian obesitas pada anak sekolah dasar.

\section{PEMBAHASAN}

\section{Hubungan pola makan dengan kejadian obesitas pada anak di SD Laboratorium Universitas Negeri Gorontalo}

Berdasarkan hasil penelitian untuk responden dengan pola makan tidak baik dan mengalami obesitas sebanyak 40 responden $(33,1 \%)$. Orang yang mengalami obesitas cenderung akan makan bila ingin makan dan bukan pada saat lapar. Terlalu banyak mengkonsumsi makanan berlemak dibandingkan makanan yang mengandung banyak serat. Ketidakseimbangan antara jumlah makanan yang masuk dan keluar mengakibatkan energi yang terus menumpuk di dalam tubuh. Konsumsi fast food yang dilakukan lebih dari 3x/minggu serta porsi makan yang lebih dari $3 x /$ sehari juga memiliki kalori dalam jumlah tinggi sehingga dapat mempercepat tingkat obesitas seseorang.

Hasil penelitian ini sejalan dengan teori Gibney, Margetts, Kearney, \& Arab (2013), yang mengemukakan bahwa asupan energi yang berlebih secara kronis akan menimbulkan kenaikan berat badan, berat badan lebih (over weight), dan obesitas. Makanan ringan yang sering dikonsumsi oleh anak-anak karena rasanya yang gurih, manis jika tidak di kontrol akan menyebabkan kegemukan karena jenis makanan tersebut termasuk tinggi kalori. Selain itu konsumsi makanan cepat saji sangat beresiko untuk mengalami obesitas pada anak karena mengandung lemak dan kolesterol.

Penelitian ini sejalan dengan penelitian yang dilakukan oleh Hendro Bidjuni et al (2014), yang mengemukakan bahwa ada hubungan antara pola makan dengan kejadian obesitas. Anak-anak jaman sekarang lebih banyak makan makanan instan, makanan cepat saji, minuman yang mengandung tinggi gula serta makanan cemilan yang sudah diproses yang tinggi kalori dan lemak namun rendah vitamin lainnya dibandingkan makanan sehat dan 
segar seperti sayur dan buah-buahan. Selain itu untuk responden dengan pola makan baik dan tidak mengalami obesitas sebanyak 33 responden $(27,2 \%)$. Dengan mengkonsumsi makanan yang beragam (karbohidrat, protein, vitamin, lemak, dan serat) setiap harinya sesuai dengan porsi dan jumlahnya membuat gizi dalam tubuh terpenuhi dengan baik. Berdasarkan hasil kuisioner didapatkan hasil bahwa banyak responden yang mengkonsumsi sayur dan buah serta minum susu setiap hari. Buah dan sayur merupakan makanan rendah kalori, kaya akan serat, vitamin dan juga mineral yang baik untuk kesehatan. Dengan konsumsi sayur dan buah yang banyak dapat mencegah terjadinya obesitas.

Pada penelitian ini didapatkan bahwa untuk responden dengan pola makan tidak baik tetapi tidak mengalami obesitas sebanyak 25 responden $(20,7 \%)$. Walaupun mereka sering mengkonsumsi makanan yang berlemak, jajan sembarangan, konsumsi junk food yang berlebihan namun responden selalu melakukan olahraga setiap minggu disekolah dan diluar sekolah, bermain larilarian/bermain karet pada saat istrahat serta bermain dirumah dengan teman seperti bersepeda/bermain bola/petak umpet yang membuat energi didalam tubuh keluar.
Responden dengan pola makan baik tetapi mengalami obesitas sebanyak 23 responden (19\%). Kebiasaan yang dikonsumsi oleh seseorang setiap hari bervariasi. Dimana, mereka mengkonsumsi makanan yang bergizi seimbang serta jumlah energinya cukup untuk tubuh. Mereka menjaga pola makan yang baik dengan mengkonsumsi sayur dan buah serta tidak makan lebih dari 3x sehari. Berdasarkan hasil obervasi dan wawancara hal tersebut disebabkan karena kurangnya aktivitas yang dilakukan. Disekolah mereka memang bermain dengan teman pada saat jam istrahat, akan tetapi ketika dirumah hal yang justru dilakukan hanya nonton TV dan bermain game. Faktor lain yang menyebabkan mereka mengalami obesitas meskipun pola makan baik yaitu riwayat obesitas orang tua mereka.

\section{Hubungan aktivitas fisik dengan kejadian obesitas pada anak di SD Laboratorium Universitas Negeri Gorontalo}

Berdasarkan hasil penelitian untuk responden yang melakukan aktivitas fisik dengan tidak baik dan mengalami obesitas sebanyak 63 responden $(52,1 \%)$. Sebagian besar energi yang masuk melalui makanan seharusnya digunakan untuk aktivitas fisik. Akan tetapi berdasarkan hasil kuisioner 
justru responden kurang melakukan aktivitas

fisik yang berat dan justru lebih banyak menghabiskan waktu dengan nonton TV dan bermain game dibandingkan dengan olahraga yang dapat membuat kalori dalam tubuh terbakar. Dengan semakin banyak berolahraga maka semakin banyak kalori yang akan hilang. Kurangnya aktivitas ini menyebabkan banyak energi yang tersimpan sebagai lemak, sehingga banyak orang yang kurang beraktivitas akan menjadi gemuk.

Menurut Syarif Damayanti (2009), meskipun aktivitas fisik hanya mempengaruhi 1/3 pengeluaran energi seseorang dengan berat normal, namun bagi orang yang memiliki kelebihan berat badan aktivitas fisik memiliki peran yang sangat penting. Olahraga yang dilakukan setiap minggu sebanyak 3 kali dengan minimal waktu 20 menit per hari dapat membuat kalori terbakar, semakin banyak berolah raga maka semakin banyak kalori yang hilang.

Penelitian ini sejalan dengan penelitian Ratu Rahayu \& Hiswani (2014), yang mengemukakan bahwa ada hubungan yang signifikan antara aktivitas fisik dengan kejadian obesitas. Sebagian besar energi yang masuk melalui makanan seharusnya digunakan untuk aktivitas fisik. Kurangnya aktivitas akan menyebabkan banyak energy yang tersimpan sebagai lemak dalam tubuh, sehingga cenderung orang yang kurang beraktivitas akan menjadi gemuk.

Hasil penelitian untuk responden yang melakukan aktivitas fisik baik dan tidak mengalami obesitas sebanyak 55 responden (45,5\%). Aktivitas fisik merupakan kegiatan yang penting dilakukan oleh anak-anak. Aktivitas yang baik tidak perlu melakukan hal yang berat. Responden selalu melakukan olahraga di sekolah setiap minggu, bersepeda, bermain bola, bermain lari-larian dan bermain karet pada saat jam istrahat tiba.dengan aktivitas fisik yang baik serta diimbangi dengan asupan makan yang baik akan mencegah seseorang mengalami obesitas.

Sesuai dengan penelitian diatas
didapatkan bahwa responden yang
melakukan aktivitas fisik tidak baik namun
tidak mengalami obesitas sebanyak 3
responden (2,4\%). Aktivitas fisik ini jika
tidak dilakukan dengan baik akan
berdampak pada energi yang justru lebih
banyak tersimpan dalam tubuh. Meskipun
responden jarang untuk berolahraga atau
hanya sekedar bermain dengan teman-
temannya hal tersebut justru tidak
menyebabkan anak mengalami obesitas.


Faktor yang menyebabkan responden tidak mengalami obesitas karena orang tua yang membiasakan anaknya untuk makan tepat waktu dengan jumlah dan jenis yang tepat, tidak jajan sembarangan di sekolah karena makanan jajanan banyak yang tidak mengandung gizi yang baik untuk kesehatan anak.

\section{KESIMPULAN}

Berdasarkan hasil penelitian dan pembahsan, maka dapat ditarik kesimpulan sebagai berikut :

1. Terdapat hubungan pola makan dengan kejadian obesitas pada anak di SD Laboratorium (LAB) Kota Gorontalo dengan presentase responden dengan pola konsumsi makan yang tidak baik sebanyak 65 orang $(53,7 \%)$ dengan nilai $\mathrm{P}-$ Value $=0,039<\alpha=0,05$.

2. Terdapat hubungan aktivitas fisik dengan kejadian obesitas pada anak di SD Laboratorium (LAB) Kota Gorontalo dengan presentase responden yang melakukan aktivitas fisik yang tidak baik sebanyak 66 orang $(54,5 \%)$ dengan nilai $=0,000<\alpha 005$.

\section{DAFTAR PUSTAKA}

Afrienny, R., Rahayu, \& Hiswani. (2014). Fakor-faktor yang Berhubungan dengan Kejadian Obesitas Pada Siswa/I Kelas VII dan VIII di SMP Negeri 34 Medan Tahun 2014. Jurnal Kesehatan Masyarakat, 1.

Bidjuni, H., Rompas, S., \& Bambuena, I. M. (2014). Hubungan Pola Makan Dengan Kejadian Obesitas Pada Anak Usia 8-10 Tahun Di SD Katolik 03 Frater Don Bosco Man.

Cahyaningsih, D. S. (2011). Pertumbuhan Perkembangan Anak dan Remaja. Jakarta : Rineka Cipta.

Cahyono, J. B., \& Suharjo, B. (2008). Gaya Hidup dan Penyakit Modern. Yogyakarta: Kanisius.

Cici Octari, N. I. (2014). Hubungan status sosial ekonomi dan Gaya Hidup dengan Kejadian Obestas pada Siswa Negeri 08 Alang Lawas Padang. Jurnal Kesehatan

Damayanti, Syarif (2009). Obesitas pada Anak. Prosiding Simposium Temu Ilmiah Akbar. Jakarta : Pusat Informasi dan Penerbitan bagian Ilmu Penyakit Dalam FKUI

Dinas Kesehatan Provinsi Gorontalo. 2017. Profil Kesehatan Provinsi Gorontalo. Gorontalo : Dinas Kesehatan Provinsi Gorontalo

Fachrunnisa, J., Abrori, C., \& Rachmawati, A. D. (2016). Analisis Faktor Resiko Kejadian Obesitas pada Anak Perkotaan di Beberapa Sekolah Dasar Kabupaten Jember. Jurnal Kedokteran , 1.

Gibney, M. J., Margetts, B. M., Kearney, J. M., \& Arab, L. (2013). Gizi Kesehatan Masyarakat. Jakarta: Buku Kedokteran EGC.

Mumpuni, Y., \& Wulandari, A. (2010). Cara Mengatasi Kegemukan. Yogyakarta: Andi. 
Nirwana, A. B. (2012). Obesitas Anak dan Pencegahannya. Yogyakarta: Nuha Medika.

Nurfatimah. (2014). Faktor-faktor Yang Berhubungan Dengan Obesitas Pada Anak Usia 6-12 Tahun Di Madrasah Ibtidaiyah Negeri Pondok Pinang Jakarta. Jurnal Keperawatan ..

Rachmatia, \& Dian, E. F. (2012). Faktor Resiko Obesitas dan Tingkat Obesitas pada Anak Sekolah Dasar Banda Aceh. Jurnal Keperawatan, 1.

Rahayu, S. 2008. Keperawatan Keluarga. Yogyakarta : Graha Ilmu.

Wong, D. d. (2009). Buku Ajar Keperawatan Pediatric Volume 1. Jakarta: Buku Kedokteran : EGC.

Yatim, F. (2008). 30 Gangguan Kesehtan pada Anak Usia Sekolah. Jakarta: Pustaka Populer Obor. 